\title{
Pelatihan Dan Pemanfaatan E-Commerce Sebagai Media Pemasaran Produk UMKM Di Desa Tales Kecamatan Ngadiluwih, Kabupaten Kediri
}

\author{
Aprilia Dian Evasar ${ }^{1}$, Yudo Bismo Utomo², dan Diana Ambarwati ${ }^{3}$ \\ Universitas Islam Kadiri, Kediri ${ }^{1,2,3}$ \\ apriliadianeva@uniska-kediri.ac.id ${ }^{1}$, yudobismo@ uniska-kediri.ac.id ${ }^{2}$, dianaambarwati@ uniska-kediri.ac.id ${ }^{3}$
}

\begin{abstract}
The implementation of community service involves one partner, the UMKM "KIRANA" Group. This partner is located in Tales Village, Ngadiluwih Subdistrict, Kediri District or about 10.5 $\mathrm{km}$ from UNISKA Kediri. This group has various businesses, including culinary and handicraft. However, the lack of promotion and sale of products that are still done traditionally and the ability of management or management that is less professional, this causes some UMKM in the village of Tales to be less developed even some of them out of business. There is another who because they still want to earn a fixed income selling it to big traders without brands, so many of whose products are recognized as products of others. The purpose of this community service is to apply e-commerce to the sale of various UMKM products in Tales Village with the intention of introducing and increasing sales turnover, while the method used is to use the method of participatory, counseling, mentoring and training. The results obtained from the implementation of community service is the existence of training assistance and e-commerce applications can increase motivation for partners to carry out marketing of their products so that their turnover increases.
\end{abstract}

Keywords: UMKM products,marketing, e-commerce.

\begin{abstract}
Abstrak
Pelaksanaan pengabdian kepada masyarakat ini melibatkan satu Mitra yaitu Kelompok UMKM "KIRANA". Mitra ini bertempat di Desa Tales, Kecamatan Ngadiluwih, Kabupaten Kediri atau berjarak sekitar 10,5 km dari UNISKA Kediri. Kelompok ini memiliki aneka usaha, antara lain aneka kuliner dan kerajinan. Namun, kurangnya promosi dan penjualan produk yang masih dilakukan secara tradisional serta kemampuan manajemen atau pengelolaan yang kurang profesional, hal tersebut yang menyebabkan beberapa UMKM di Desa Tales kurang berkembang bahkan beberapa diantaranya gulung tikar. Ada lagi yang karena tetap ingin memperoleh pendapatan tetap menjualnya kepada pedagang besar tanpa merk, sehingga banyak yang produknya diakui sebagai produk orang lain. Tujuan dari pelaksanaan pengabdian kepada masyarakat ini adalah untuk menerapkan $e$-commerce terhadap penjualan aneka produk UMKM yang ada di Desa Tales dengan maksud mengenalkan dan meningkatkan omset penjualannya, sedangkan metode yang digunakan adalah dengan menggunakan metode parsitipatif, penyuluhan, pendampingan dan pelatihan. Hasil yang diperoleh dari pelaksanaan pengabdian kepada masyarakat ini yaitu dengan adanya bantuan pelatihan dan aplikasi $e$ commerce dapat meningkatkan motivasi bagi mitra untuk melaksanakan pemasaran terhadap produknya supaya omsetnya meningkat.
\end{abstract}

Kata Kunci: produk UMKM, pemasaran, e-commerce. 


\section{Pendahuluan}

Pelaksanaan pengabdian kepada masyarakat ini melibatkan satu Mitra yakni Kelompok UMKM "KIRANA" di Desa Tales. Mitra ini tepatnya bertempat di Desa Tales, Kecamatan Ngadiluwih, Kabupaten Kediri atau berjarak sekitar 10,5 km dari Universitas Islam Kadiri Kediri.

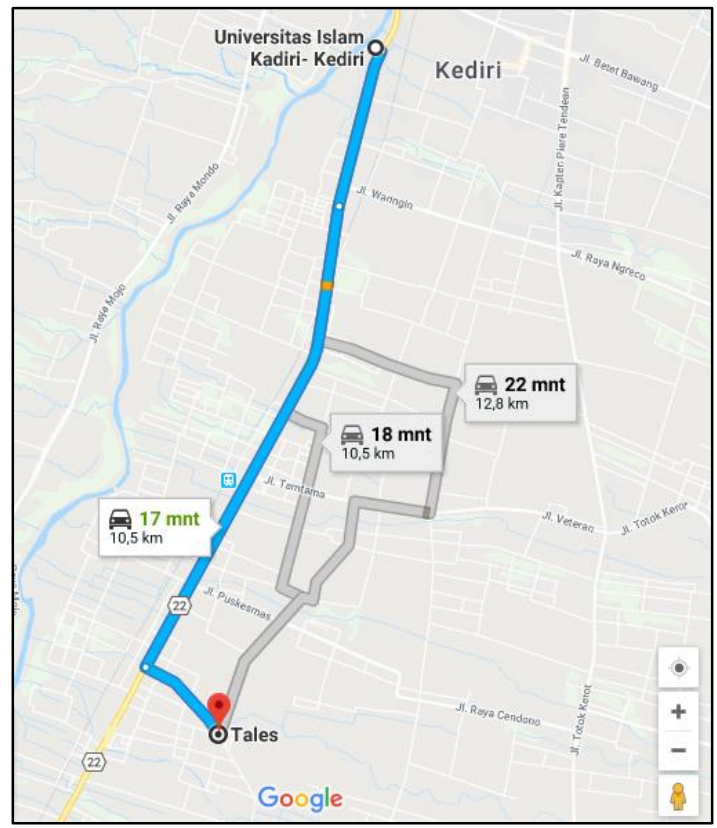

Gambar 1. Peta Lokasi Mitra Sasaran

Mitra ini merupakan perkumpulan Usaha Mikro Kecil Menengah (UMKM) di Desa Tales. UMKM mempunyai peran penting dan strategis dalam pembangunan ekonomi nasional (Adnan Husada Putra, 2016). Dari hal tersebut, dapat disimpulkan bahwa UMKM itu sendiri memiliki peranan yang sangat penting dan strategis dalam pembangunan ekonomi yang ada di Indonesia, diantaranya penyerapan tenaga kerja supaya jumlah pengangguran yang ada di Indonesia berkurang dan dapat mengembangkan kegiatan ekonomi lokal serta memberdayakan masyarakat sekitar. Kelompok UMKM ini memiliki usaha antara lain aneka makanan kuliner (kripik, nugget, kue dan telur asin) dan aneka kerajinan (tas, bros, dan genteng rumah). Besarnya minat pasar untuk produk yang dihasilkan UMKM adalah salah satu peluang bisnis yang menguntungkan.

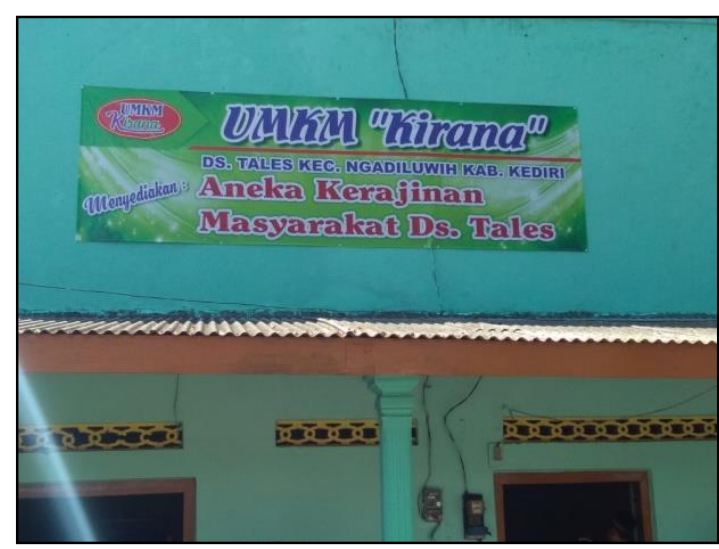

Gambar 2. Kios UMKM "KIRANA" Desa Tales

Namun kurangnya promosi yang dilakukan pelaku usaha menyebabkan beberapa UMKM di Desa Tales kurang berkembang. Ada lagi yang karena tetap ingin memperoleh pendapatan tetap menjualnya kepada pedagang besar tanpa merk sehingga banyak yang produknya diakui sebagai produk orang lain. Padahal jika kita mampu mendayagunakan aneka produk tersebut tidak menutup kemungkinan akan menaikkan pendapatan masyarakat dan daerah.

Permasalahan yang sering dihadapi oleh mitra UMKM "KIRANA" adalah berkaitan dengan masalah kemampuan manajemen atau pengelolaan yang kurang profesional. Masalah-masalah manajemen ini meliputi, masalah struktur permodalan, personalia dan pemasaran. Selain masalahmasalah tersebut, ada juga masalah teknis yang sering dijumpai, yaitu belum dimilikinya sistem administrasi keuangan dan manajemen yang baik, masalah bagaimana menyusun proposal dan membuat studi kelayakan untuk memperoleh pinjaman baik dari bank maupun modal ventura, karena masalah menyusun perencanaan bisnis karena persaingan dalam merebut pasar semakin ketat, masalah akses terhadap teknologi terutama bila pasar dikuasai oleh perusahaan atau group bisnis tertentu dan selera konsumen yang cepat berubah, masalah memperoleh bahan baku dan tingginya harga bahan baku karena ada 
sebagian UMKM yang harus mengimpor bahan baku produksinya, masalah inovasi perbaikan kualitas barang dan efisiensi.

Penjualan produk UMKM yang rendah dan masih dilakukan secara tradisional mengakibatkan tidak dapat berkembangnya usaha, sehingga solusi yang ditawarkan untuk menangani permasalahan yang dihadapi oleh Mitra berupa pembuatan aplikasi e-commerce berupa website dan pelatihan pemanfaatan guna meningkatkan penjualan produk UMKM "KIRANA". E-Commerce dapat terjadi antara organisasi bisnis dengan konsumen, meliputi penggunaan Internet dan World Wide Web untuk penjualan produk dan pelayanan untuk konsumen (Siti Maryama, 2013).

Berdasarkan uraian tersebut diatas, dapat disimpulkan bahwa e-commerce itu sendiri dapat terjadi dikarenakan adanya hubungan antara organisasi atau kelompok bisnis dengan customer, dengan bantuan penggunaan internet dan media website untuk penjualan produk serta melayani customer supaya lebih efektif dan efisien.

Target luaran dari pelaksanaan pengabdian kepada masyarakat ini adalah pembuatan aplikasi teknologi tepat guna $e$-commerce berupa website sebagai media promosi sekaligus media pemasaran produk Mitra.

\section{Pelaksanaan Dan Metode}

Metode adalah suatu cara yang ditempuh untuk mencapai tujuan tertentu (Sugiyono, 2016). Dari pengertian tersebut, metode pelaksanaan dapat diartikan sebagai suatu kegiatan yang dikerjakan dengan cara tertentu demi tercapainya target yang telah ditentukan sebelumnya.

Pelaksanaan program pengabdian kepada masyarakat ini dilakukan dengan menggunakan metode parsitipatif, penyuluhan, pendampingan dan pelatihan di lokasi Mitra yang berada di Desa Tales, Kecamatan Ngadiluwih, Kabupaten Kediri. Untuk pelaksanaan program pengabdian kepada masyarakat ini, akan diuraikan pada tabel 1 berikut ini.
Tabel 1. Kegiatan dan Metode

\begin{tabular}{|c|c|c|c|}
\hline No & Kegiatan & Metode & $\begin{array}{c}\text { Bahan/ } \\
\text { Alat }\end{array}$ \\
\hline 1 & $\begin{array}{l}\text { Penjelasan } \\
\text { mengenai } \\
\text { manfaat sistem } \\
\text { informasi } \\
\text { manajemen }\end{array}$ & $\begin{array}{l}\text { Diskusi, } \\
\text { pengamatan, } \\
\text { tanya Jawab }\end{array}$ & $\begin{array}{l}\text { Makalah } \\
\text { gambar } \\
\text { dan slide }\end{array}$ \\
\hline 2 & $\begin{array}{l}\text { Pelatihan } \\
\text { mengenai } \\
\text { manajemen } \\
\text { pemasaran }\end{array}$ & $\begin{array}{l}\text { Demonstrasi, } \\
\text { praktek dan } \\
\text { tanya jawab }\end{array}$ & $\begin{array}{l}\text { Alat dan } \\
\text { bahan }\end{array}$ \\
\hline 3 & $\begin{array}{l}\text { Membuat } \\
\text { desain atau } \\
\text { rancangan } \\
\text { aplikasi } \\
\text { ecommerce }\end{array}$ & $\begin{array}{l}\text { Demonstrasi, } \\
\text { praktek dan } \\
\text { tanya Jawab }\end{array}$ & $\begin{array}{l}\text { Alat dan } \\
\text { bahan }\end{array}$ \\
\hline 4 & $\begin{array}{l}\text { Pelatihan } \\
\text { pengaplikasian } \\
\text { sistem } \\
\text { ecommerce }\end{array}$ & $\begin{array}{l}\text { Demonstrasi, } \\
\text { praktek dan } \\
\text { tanya jawab }\end{array}$ & $\begin{array}{l}\text { Alat dan } \\
\text { bahan }\end{array}$ \\
\hline 5 & $\begin{array}{l}\text { Pelatihan dan } \\
\text { pembinaan } \\
\text { tenaga kerja }\end{array}$ & $\begin{array}{l}\text { Demonstrasi, } \\
\text { praktek, } \\
\text { tanya jawab }\end{array}$ & Produk \\
\hline
\end{tabular}

(Sumber : Penulis, 2019)

\section{Hasil dan Pembahasan}

Pelaksanaan pengabdian kepada masyarakat ini melibatkan satu Mitra, yaitu Kelompok UMKM "KIRANA" yang lokasinya berada di Desa Tales, Kecamatan Ngadiluwih, Kabupaten Kediri, dikarenakan UMKM "KIRANA" ini terdapat suatu permasalahan yang dihadapi, yaitu berkaitan dengan masalah kemampuan manajemen atau pengelolaan yang kurang profesional.

Proses kegiatan pertama dari pelaksanaan pengabdian kepada masyarakat, yaitu menjelaskan mengenai pemanfaatan sistem informasi manajemen kepada mitra. Sistem informasi adalah kumpulan komponen didalam suatu organisasi yang berfungsi sebagai pengolahan untuk menghasilkan sebuah laporan-laporan yang disajikan kepada pihak tertentu (Sri Handayani, 2016).

Sistem informasi manajemen adalah bagian dari sebuah sistem informasi, jadi berdasarkan uraian diatas, pengertian dari 
sistem informasi manajemen adalah suatu sistem yang dibuat untuk mengolah dari data mentah menjadi sebuah laporan yang berharga, supaya bisa disajikan kepada stackholder yang membutuhkan.

Dari proses pertama, yaitu persiapan, sampai dengan proses terakhir, yaitu pelatihan dan pembinaan tenaga kerja, dilaksanakan selama 5 (lima) bulan, di mulai dari bulan April sampai dengan bulan Agustus. Untuk pelaksanaan kegiatan akan diuraikan pada tabel 2 berikut ini.

Tabel 2. Pelaksanaan Kegiatan BULAN

\begin{tabular}{|c|c|c|c|c|c|c|}
\hline \multirow[t]{2}{*}{ No } & \multirow[t]{2}{*}{ KEGIATAN } & \multicolumn{5}{|c|}{$\begin{array}{c}\text { (April - Agustus } \\
\text { 2019) }\end{array}$} \\
\hline & & 4 & 5 & 6 & 7 & 8 \\
\hline 1 & $\begin{array}{l}\text { Penjelasan } \\
\text { mengenai } \\
\text { manfaat sistem } \\
\text { informasi } \\
\text { manajemen }\end{array}$ & & & & & \\
\hline 2 & $\begin{array}{l}\text { Pelatihan } \\
\text { mengenai } \\
\text { manajemen } \\
\text { pemasaran }\end{array}$ & & & & & \\
\hline 3 & $\begin{array}{l}\text { Membuat } \\
\text { desain atau } \\
\text { rancangan } \\
\text { aplikasi } \\
\text { ecommerce }\end{array}$ & & & & & \\
\hline 4 & $\begin{array}{l}\text { Pelatihan } \\
\text { pengaplikasi- } \\
\text { an sistem } \\
\text { ecommerce }\end{array}$ & & & & & \\
\hline 5 & $\begin{array}{l}\text { Pelatihan dan } \\
\text { pembinaan } \\
\text { tenaga kerja }\end{array}$ & & & & & \\
\hline
\end{tabular}

(Sumber : Penulis, 2019)

Tahapan dari pelaksanaan ini adalah memberikan pendampingan kepada anggota dan pengelola Kelompok UMKM "KIRANA" Desa Tales, untuk mengetahui perkembangan usaha dan menginventarisir permasalahan yang dihadapi oleh mitra.

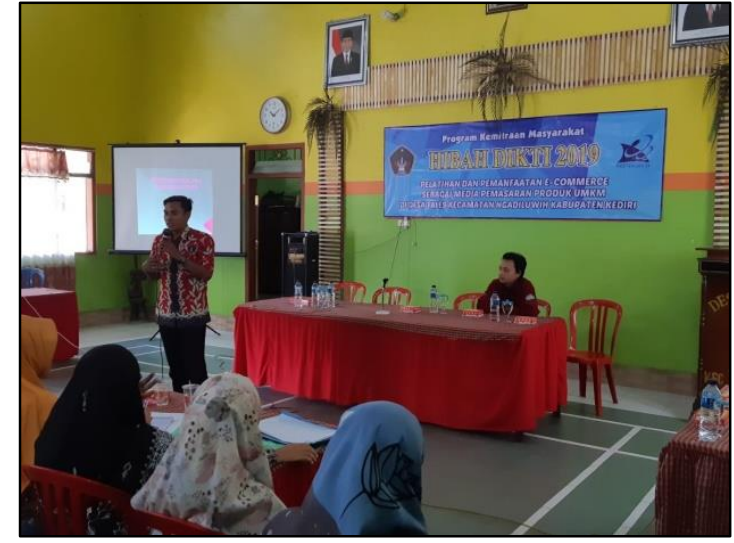

Gambar 3. Kegiatan Pemanfaatan Sistem Informasi Manajemen

Proses selanjutnya, dilakukan pelatihan mengenai manajemen pemasaran. Manajemen pemasaran adalah ilmu untuk mengolah dalam menentukan target pasar, kemudian mendapatkan customer, setelah itu menjaga customer, sehingga menciptakan hubungan yang kuat antara perusahaan dengan customer untuk menangkap nilai dari customer sebagai imbalan (Kotler dan Keller, 2016). Dari pengertian diatas, dapat disimpulkan bahwa manajemen pemasaran adalah suatu proses mengolah kebutuhan, keinginan dan permintaan demi menarik pelanggan baru dengan menciptakan suatu produk yang sesuai dengan keinginan customer dan menetapkan harga yang menarik dengan memegang prinsip kepuasan pelanggan.

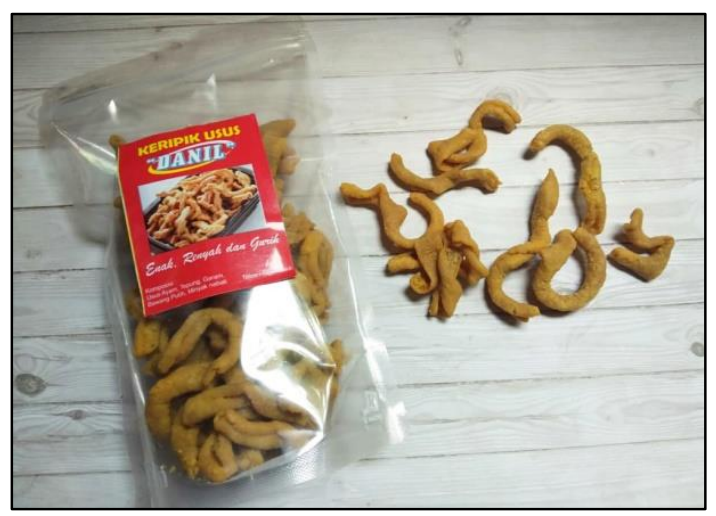

Gambar 4. Pelatihan Manajemen Pemasaran 


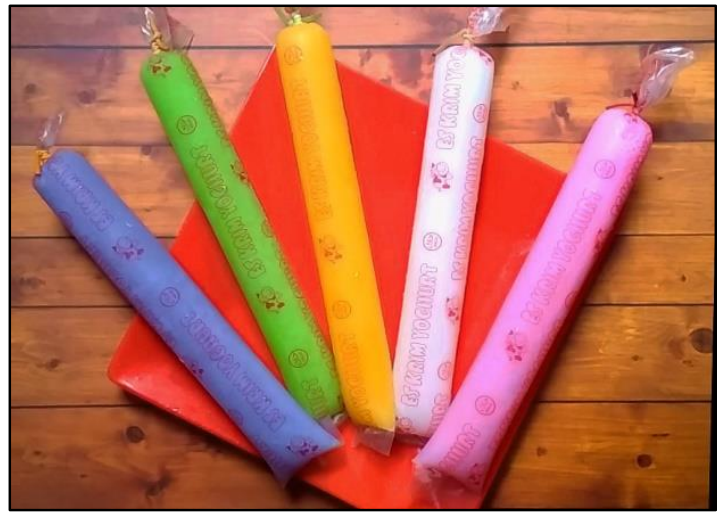

Gambar 5. Pelatihan Manajemen Pemasaran Pembuatan Desain dan Layout Produk

Tahapan pelaksanaan ini adalah dilakukan pelatihan cara pembuatan merk dan logo serta desain dan layout produk, karena mitra mengemas produk secara ala kadarnya, sederhana dan tanpa merk, kalaupun ada merk menggunakan kertas fotocopi, serta kemasan yang digunakan pun terlalu tipis, sehingga minat beli customer berkurang.

Proses kegiatan ketiga, dilakukan pembuatan desain dan perancangan aplikasi e-commerce berbasis website. ECommerce merupakan suatu hubungan antara organisasi atau kelompok bisnis dengan customer, dengan bantuan penggunaan internet dan media website yang digunakan untuk penjualan produk serta melayani customer supaya lebih efektif dan efisien tanpa harus customer datang ke tempat.

Yang membedakan antara proses jual dan beli produk pada sistem ecommerce dengan proses jual dan beli produk secara tradisional adalah semua proses yang dimulai dari mencari informasi mengenai barang atau jasa yang diperlukan, kemudian melakukan pemesanan dan yang terakhir proses pembayaran di lakukan secara elektronik.

Penggolongan e-commerce pada umumnya dilakukan berdasarkan sifat transaksinya (Mahir Pradana, 2015), yaitu:
Tabel 3. Penggolongan e-commerce

\begin{tabular}{lccc}
\hline Kategori & Business & Consumer & Government \\
\hline Business & B2B & B2C & B2G \\
\hline Consumer & C2B & C2C & C2G \\
\hline Government & G2B & G2C & G2G \\
\hline
\end{tabular}

1. Business to Business (B2B)

Merupakan sebuah transaksi dimana perusahaan atau pebisnis menawarkan untuk menjual atau membeli produk dan jasanya kepada entitas perusahaan atau pebisnis yang lainnya.

2. Business to Consumer (B2C)

Merupakan sebuah transaksi dimana perusahaan atau pebisnis menawarkan untuk menjual atau membeli produk dan jasanya kepada customer.

3. Business to Government (B2G)

Merupakan sebuah transaksi dimana perusahaan atau pebisnis menawarkan untuk menjual atau membeli produk dan jasanya kepada pemerintah.

4. Consumer to Business (C2B)

Merupakan sebuah transaksi dimana customer yang menawarkan untuk menjual atau membeli produk dan jasanya kepada perusahaan atau pebisnis.

5. Consumer to Consumer (C2C)

Merupakan sebuah transaksi dimana customer menawarkan untuk menjual produk dan jasanya secara langsung kepada customer lainnya.

6. Consumer to Government $(\mathrm{C} 2 \mathrm{G})$

Merupakan sebuah transaksi dimana customer menawarkan untuk menjual atau membeli produk dan jasanya kepada pemerintah.

7. Government to Business (G2B)

Merupakan sebuah transaksi dimana pemerintah menawarkan untuk menjual atau membeli produk dan jasanya kepada perusahaan atau pebisnis. 
8. Government to Consumer (G2C)

Merupakan sebuah transaksi dimana pemerintah menawarkan untuk menjual atau membeli produk dan jasanya kepada customer.

9. Government to Government $(\mathrm{G} 2 \mathrm{G})$

Merupakan sebuah transaksi dimana pemerintah menawarkan untuk menjual atau membeli produk dan jasanya kepada entitas pemerintah yang lainnya.

Pada sistem e-commerce (Shabur Miftah Maulana, 2015), terdapat 3 metode pembayaran pada saat customer melakukan transaksi, yaitu :

\section{Credit Cart}

Pembayaran jenis metode ini dilakukan secara langsung atau saat itu juga, dimana mencakup pasar yang sangat luas yaitu seluruh dunia.

2. Transfer

Pembayaran jenis metode ini lebih aman, dikarenakan melibatkan lembaga perbankan sebagai institusi yang menangani transfer pembayaran transaksi. Akan tetapi, membutuhkan biaya fee atau biaya tambahan bagi pihak lembaga perbankan untuk mengirim sejumlah uang ke Negara lain ataupun beda bank.

3. Cash on Delivery (COD)

Pembayaran jenis metode ini dilakukan dengan cara bayar di tempat, dimana pembayaran ini hanya bisa dilakukan jika konsumen langsung datang ke toko tempat produsen menjual produknya atau berada dalam satu wilayah yang sama dengan penyedia jasa pengiriman, seperti: JNE, Si Cepat, JnT, Pos Kilat, gojek, grab, dll.

Jenis layanan e-commerce yang dimaksud dalam kegiatan pengabdian kepada masyarakat ini termasuk dalam kategori Business to Consumer (B2C), dikarenakan aktivitasnya pebisnis (dalam kasus ini bernama UMKM "Kirana") ini memberikan inventaris berupa website kepada pelaku usaha yang ada di desa Tales, untuk menjual produknya kepada customer secara online dengan media internet melalui penyedia layanan $e$-commerce.
Pada pengabdian kepada masyarakat kali ini, aplikasi sistem e-commerce dibuat berbasis website. Yang dimaksud dengan website adalah sebuah software yang berfungsi untuk menampilkan dokumen dokumen pada suatu website yang membuat pengguna dapat mengakses internet melalui software yang terkoneksi dengan internet (Mara Destiningrum, 2017).

Dari pengertian tersebut diatas dapat disimpulkan bahwa website merupakan sebuah aplikasi perangkat lunak yang mempunyai fungsi untuk menampilkan informasi baik data teks, gambar, video, musik maupun animasi lainnya kepada stakeholder yang terhubung dengan media internet.

Tahapan dari kegiatan ini adalah mendesain sistem secara keseluruhan untuk aplikasi e-commerce. Desain dibuat mulai dari perancangan database di XAMPP, form, dan alur aplikasi yang akan digunakan. Desain yang dihasilkan dilanjutkan dengan pembelian domain dan hosing pembuatan website e-commerce dengan alamat www.kiranastore.co.id .

Domain merupakan sebuah nama unik yang dibuat untuk menidentifikasikan nama server hosting pada jaringan internet, sehingga stakeholder mempermudah penyebutan atau pemanggilan informasi pada sebuah server. Sedangkan hosting merupakan tempat penyimpanan file dokumen yang ada di sebuah website. Ibarat kata domain adalah sebuah alamat, sedangkan hosting adalah rumahnya.

Manfaat yang diperoleh perusahaan atau pebisnis dalam kegiatan Abdimas ini bernama "UMKM Kirana" menggunakan layanan aplikasi e-commerce berbasis website, antara lain sebagai berikut:

1. Melayani customer tanpa batas waktu. Dengan adanya aplikasi e-commerce memungkinkan customer dapat melakukan proses transaksi jual-beli produk 24 jam non stop tanpa harus terikat waktu buka ataupun tutup.

2. Mendapatkan customer baru dan mempertahankan customer yang lama tetap bertahan. 
Dengan adanya aplikasi e-commerce ini, memungkinkan perusahaan atau pebisnis mempertahankan customer yang lama, dikarenakan customer tidak perlu repot datang ke tempat dan pebisnis mendapatkan customer baru, baik itu berasal dari customer lokal, domestik maupun luar negeri.

3. Meningkatkan mutu layanan.

Dengan adanya aplikasi e-commerce ini, pebisnis dapat meningkatkan mutu pelayanan dengan melakukan interaksi yang lebih personal dengan customer, dikarenakan aplikasi e-commerce ini dilengkapi contact person yang terhubung langsung dengan admin melalui whatsapp.

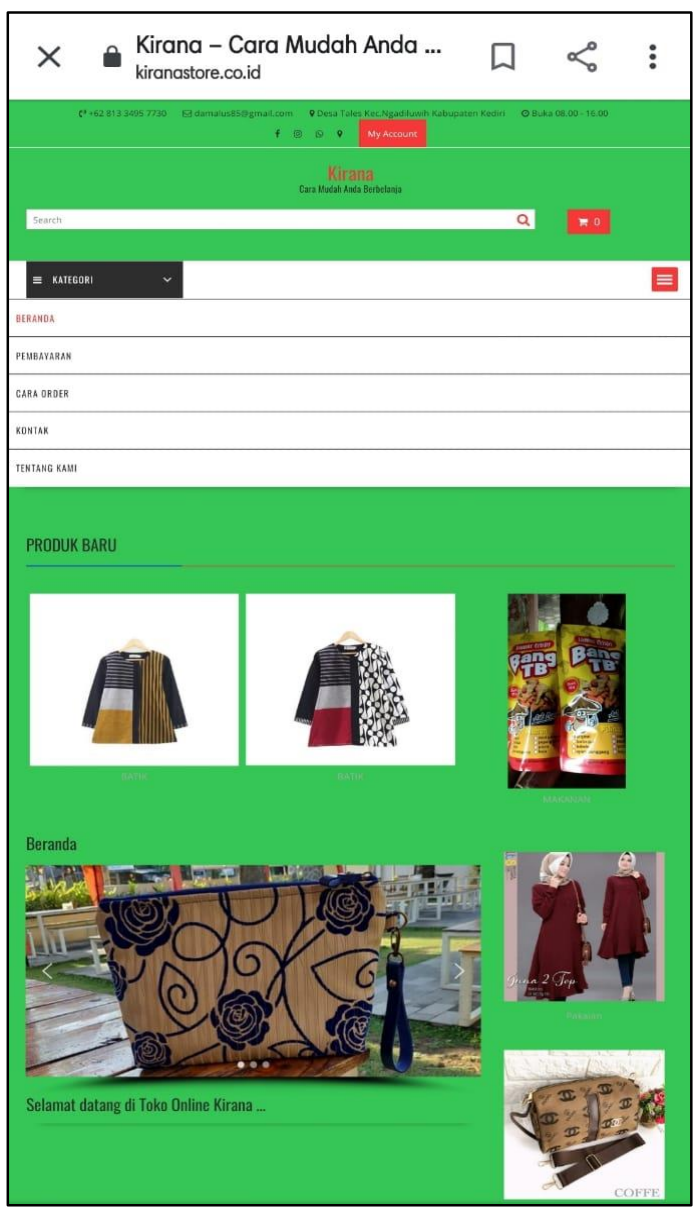

Gambar 6. Halaman Utama Website Kiranastore

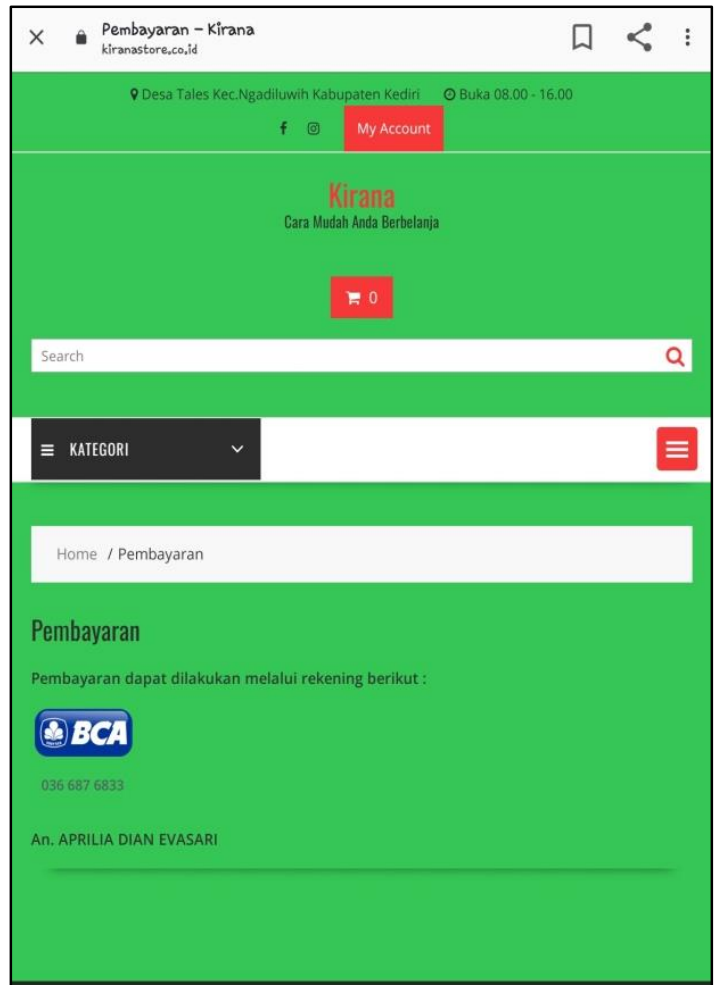

Gambar 7. Halaman Pembayaran Kiranastore

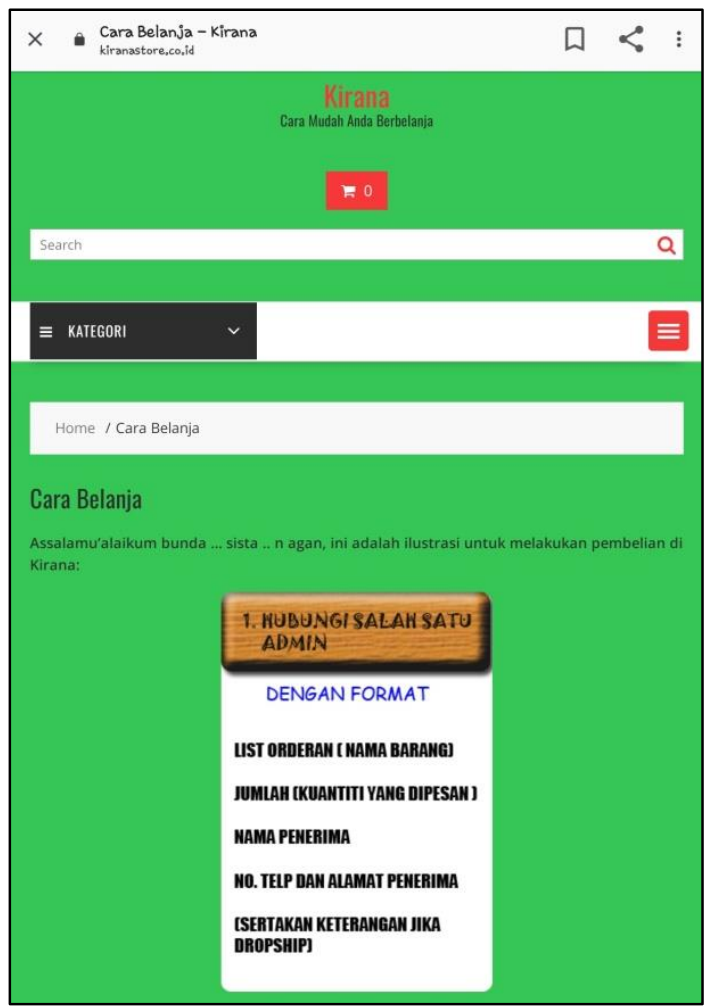

Gambar 8. Halaman Cara Order Kiranastore 


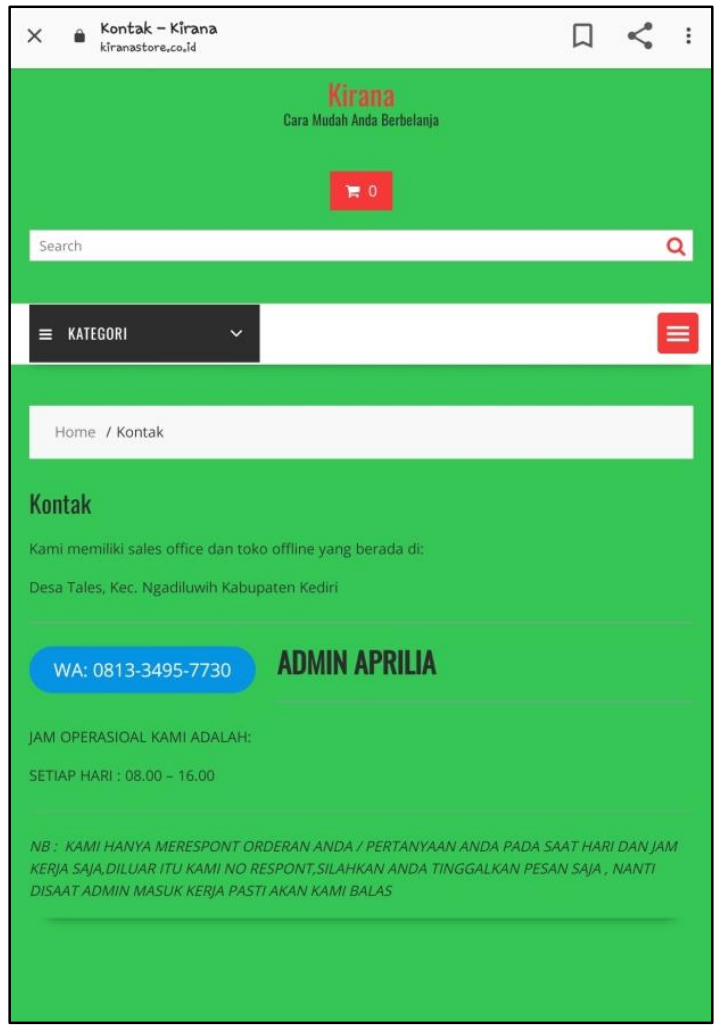

Gambar 9. Halaman Contact Person Kiranastore

Setelah aplikasi $e$-commerce berbasis website ini dibuat, langkah selanjutnya bagi UMKM Kirana adalah untuk memikirkan bagaimana cara untuk memasarkannya. Pemasaran tidak hanya membicarakan tentang desain produk, harga produk maupun mendistribusikan produk, akan tetapi memberitahukan kepada customer luas agar produk yang di jual oleh pelaku usaha di desa Tales tersebut dikenal dan dibeli oleh customer lokal, domestik maupun luar negeri. Pemasaran yang dimaksudkan hal ini adalah promosi.

Promosi pertama yang akan dilakukan oleh UMKM Kirana adalah dengan cara mengenalkan produk baik secara offline maupun online dengan memanfaatkan sosial media bernama facebook dan instagram. Promosi kedua yang akan dilakukan oleh UMKM Kirana yaitu dengan cara memberikan harga diskon, supaya customer tertarik membeli produk yang dijual oleh pelaku usaha desa Tales yang ada di laman www.kiranastore.co.id.
Proses kegiatan keempat, dilakukan pelatihan pengaplikasian sistem $e$ commerce kepada mitra. Tahapan dari kegiatan ini adalah sejumlah anggota dan pengelola dilatih dan diberikan pendampingan bagaimana cara menggunakan dan mengelola website yang telah dibuat, serta sejumlah fitur yang ada di aplikasi tersebut diperkenalkan dan langsung dicoba. Selain itu peserta pelatihan juga diberikan pendampingan bagaimana memanfaatkan telepon seluler untuk dapat mengakses sebuah website.

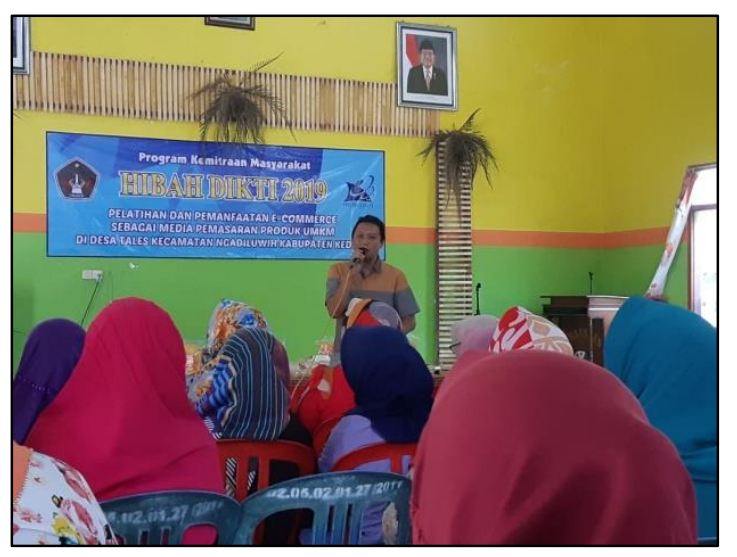

Gambar 10. Pelatihan Pengaplikasian Sistem

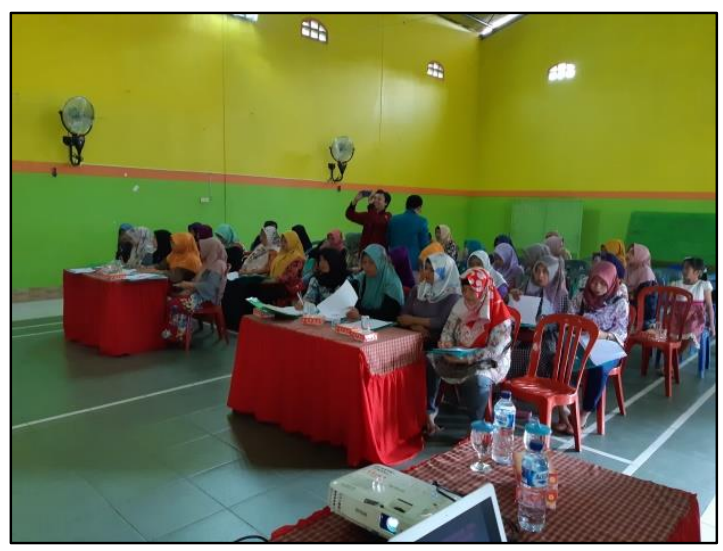

Gambar 11. Pelatihan Tenaga Kerja

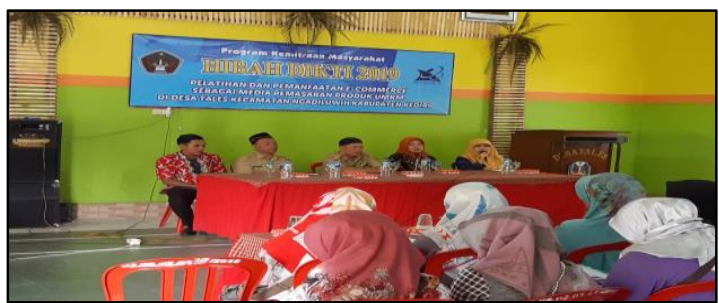

Gambar 12. Pembinaan Tenaga Kerja 
Proses terakhir dari kegiatan pengabdian kepada masyarakat adalah tahap pelatihan dan pembinaan tenaga kerja. Pada kegiatan ini para pelaku yang terlibat dalam UMKM di Desa Tales diberikan pelatihan terkait manajemen pemasaran dan MSDM, Sistem Informasi Manajemen dan e-commerce serta keuangan sederhana dan desain kemasan. Dikarenakan rata-rata para pelaku UMKM masih bekerja sendiri, sehingga para pelaku UMKM ini yang diberikan pelatihan terutama terkait pemasaran, pembagian pekerjaan, e-commerce, pembukuan keuangan secara sederhana dan desain kemasan produk.

\section{Penutup}

\section{Simpulan}

Dari kegiatan pengabdian kepada masyarakat yang telah dilaksanakan dapat disimpulkan sebagai berikut :

1. Kegiatan pengabdian masyarakat yang dilakukan terhadap mitra kelompok UMKM "KIRANA" Desa Tales sangat membantu terutama dalam kegaiatan pemasaran.

2. Dengan adanya bantuan pelatihan dan aplikasi e-commerce dapat meningkatkan motivasi bagi mitra untuk melaksanakan pemasaran terhadap produknya.

3. Minimnya pengetahuan mitra tentang manajemen pemasaran, MSDM, Sistem Informasi Manajemen, $e$ commerce, keuangan sederhana serta desain kemasan, sehingga dengan adanya pembinaan dan pelatihan di bidang-bidang tersebut membuat anggota mitra menjadi mengetahui tentang permsalahan dibidang tersebut.

4. Perlu adanya perhatian dari pemerinah untuk pengembangan usaha dan perlindungan terhadap usaha kecil dan menengah.

5. Jenis layanan e-commerce yang dimaksud dalam kegiatan pengabdian kepada masyarakat ini termasuk dalam kategori Business to Consumer (B2C), dikarenakan aktivitasnya UMKM "Kirana" ini memberikan inventaris berupa website kepada pelaku usaha yang ada di desa Tales, untuk menjual produknya kepada customer secara online dengan media internet.

\section{Saran}

Perlu adanya tindak lanjut dari program ini, sehingga bisa berkelanjutan yaitu dengan mendapatkan pendanaan dari pemerintah dan pemerintah harus senantiasa melindungi para pelaku usaha kecil yang mempunyai keinginan naik kelas di bidang bisnisnya dengan mengendalikan produk impor yang masuk agar tidak mematikan usaha lokal.

\section{Daftar Pustaka}

Abidin. 2010. Pengembangan Usaha Mikro Kecil dan Menengah (UMKM Sebagai Kekuatan Strategis Dalam Mempercepat Pembangunan Daerah. STIE Nobel Indonesia, Makasar.

Adnan, Husada Putra. 2016. Peran UMKM Dalam Pembangunan dan Kesejahteraan Masyarakat Kabupaten Blora. Jurnal Analisa Sosiologi. Oktober 2016.

Destiningrum, Mara, dkk. 2017. Sistem Informasi Penjadwalan Dokter Berbasis Web Dengan Menggunakan Framework Codeigniter. Jurnal Teknoinfo. Vol. 11. No. 2. Oktober 2017

Handayani, Sri, dkk. 2016. Sistem Informasi E-Commerce Untuk Jaringan Penjualan Sepeda Motor Bekas Kabupaten Kampar (Studi Kasus Adira Finance). Jurnal Rekayasa Dan Manajemen Sistem Informasi. Vol. 2. No 2. Agustus 2016.

Irmawati, Dewi. 2011. Pemanfaatan $E$ Commerce Dalam Dunia Bisnis. 
Jurnal Ilmiah Orasi Bisnis. Edisi keVI. November 2011.

Kotler, Philip and Kevin Lane Keller. 2016. Marketing Management. 15e New jersey: Person Prentice Hall, Inc.

Maryama, Siti. 2013. Penerapan ECommerce Dalam Meningkatkan Daya Saing Usaha. Jurnal Liquidity. Vol. 2. No. 1. Januari-Juni 2013.

Pradana, Mahir. 2015. Klasifikasi JenisJenis Bisnis E-Commerce Di Indonesia. Jurnal Neo-bis. Vol. 9. No.2. Desember 2015.

Setiarso, dkk. 2012. Studi Sosial Ekonomi Usaha Budidaaya ternak Itik Di Desa Pesirugan Kecamatan Margadana Kota Tegal. Laporan Hasil Penelitian.

Shabur, Miftah Maulana, dkk. 2015. Implementasi E-Commerce Sebagai Media Penjualan Online (Sudi Kasus Pada Toko Pastbrik Kota Malang). Jurnal Administrasi Bisnis. Vol. 29 No. 1 Desember 2015.

Sugiyono, Prof. 2016. Metode Penelitian (Pendekatan Kuantitatif, Kualitatif, dan $R \& D)$. Alfabeta: Bandung.

Tjiptono, F. 2002. Manajemen Jasa. Edisi kedua, cetakan ketiga. Penerbit Andi,Yogyakarta. 